\title{
POLA BAKTERI PADA URIN PASIEN YANG MENGGUNAKAN KATETER URETRA DI RUANG PERAWATAN INTENSIF RSUP PROF. DR. R. D. KANDOU MANADO
}

\author{
${ }^{1}$ Melisa P Chandra \\ ${ }^{2}$ Olivia Waworuntu \\ ${ }^{2}$ Velma Buntuan
}

\author{
${ }^{1}$ Kandidat Skripsi Fakultas Kedokteran Univeristas Sam Ratulangi Manado \\ ${ }^{2}$ Bagian Mikrobiologi Fakultas Kedokteran Universitas Sam Ratulangi Manado \\ Email: mei_hoa05@yahoo.com
}

\begin{abstract}
Urinary catheterization as a part of invasive procedure application poses the risk of nosocomial infection to intensive care unit patients. The probability of nosocomial infection increases in accordance to the period of catheterization; longer catheterization time yields higher chances for microbial contamination on urinary catheter as catheterization provides an opening for microbial invasion into the urinary track. There are various pathogens commonly associated with catheterization including Escherichia coli, Klebsiella pneumonia, Proteus mirabili, Pseudomonas aeruginosa, Enterobacter, Staphylococcus aureus, Enterococcus fecalis, Serratia and Candida. The main objective of this research project is to observe bacterial pattern of urine from catheterized intensive care unit patients in the Prof. DR. R. D. Kandou Public Hospital Manado. A total of 20 urine samples were obtained, one sample from each individual catheter over 2 months period. Each collected sample is subsequently passed on to microbiology laboratory to undergo bacteria identification process via culture media. The preliminary results show that the identified bacterial pattern is Staphylococcus aureus, Candida, Streptococcus, Diplococcus, Proteus vulgaris, Lactobacillus, Bacillus subtilis, Enterobacter aglomerans, Citrobacter freundii dan Shigella. Following an in-depth multi-dimensional analysis of preliminary research results, the conclusion can be drawn that the most commonly found bacteria is Staphylococcus aureus. This study is part of growing body of microbiology research in catheter-related bacterial pattern and nosocomial infection; this research project will contribute to future research on similar topics.
\end{abstract}

Keywords: bacteria, bacterial pattern, urinary catheter, nosocomial infection, intensive care unit.

\begin{abstract}
Abstrak: Kateterisasi urin adalah bagian dari penggunaan prosedur invasif membawa resiko infeksi nosokomial bagi pasien yang dirawat di ruang perawatan intensif. Semakin lama kateter terpasang maka peluang kateter terkontaminasi oleh mikroba semakin besar, karena penggunaan kateter memungkinakan jalur masuk mikroba ke dalam saluran kemih.Terdapat berbagai macam patogen yang menyebabkan ISK yang diasosiasikan dengan kateterisasi termasuk Escherichia coli, Klebsiella pneumoniae, Proteus mirabilis, Pseudomonas aeruginosa, Enterobacter, Staphylococcus aureus, Enterococcus fecalis, Serratia, Candida. Tujuan dari penelitian ini adalah untuk mengetahui pola bakteri pada urin pasien yang menggunakan kateter uretra di ruang perawatan intensif RSUP. Prof. Dr. R. D. Kandou Manado sebanyak 20 sampel. Sampel di ambil dari urin kateter pasien yang di rawat di ruang perawatan intensif. Identifikasi bakteri dilakukan dengan menggunakan media kultur. Hasil dari kultur urin menunjukan pola bakteri yang berhasil diidentifikasi yakni Staphylococcus aureus, Candida, Streptococcus, Diplococcus, Proteus vulgaris, Lactobacillus, Bacillus subtilis, Enterobacter aglomerans, Citrobacter freundii dan Shigella. Dari hasil kesimpulan pada penelitian ini didapatkan jenis bakteri yang paling banyak ditemukan adalah Staphylococcus aereus. Mengikuti analisis data hasil penelitian beberapa saran tentang proses penelitian lebih lanjut akan diusulkan.
\end{abstract}

Kata kunci: bakteri, pola kuman, kateter uretra, infeksi nosocomial, ruang perawatan intensif. 
Kateterisasi urin adalah penyisipan kateter ke dalam kandung kemih pasien yang digunakan di Rumah Sakit untuk mempertahankan proses pengeluaran urin pada pasien yang menjalani operasi, pasien yang sakit kritis, pasien yang terbatas pada tempat tidur dan merupakan pilihan pengobatan untuk pasien dengan beberapa jenis inkontinensia urin termasuk retensi urin dan obstruksi kandung kemih. ${ }^{1}$ Urin didefinisikan oleh Merriam-Webster Dictionary sebagai cairan yang sedikit asam yang kaya akan hasil metabolisme protein dengan garam dan pigmen berwarna kuning yang jelas yang disekresikan oleh ginjal. Kateter merupakan alat yang digunakan sebagai saluran untuk mengalirkan urin dari kandung kemih ke dalam kantong atau wadah terpasang. ${ }^{2}$

Menurut Inweregbu dkk kateterisasi urin sebagai bagian dari penggunaan prosedur invasif membawa resiko infeksi nosokomial bagi pasien yang dirawat di ruang perawatan intensif. Berdasarkan studi di Eropa tentang prevalensi infeksi di ruang perawatan intensif yang melibatkan lebih dari 4500 pasien, prevalensi infeksi nosokomial di ruang perawatan intensif adalah 20.6\%. Infeksi nosokomial di ruang perawatan intensif pada umumnya disebabkan oleh bakteri gram positif dengan bakteri Staphylococcus aureus sebagai patogen utama. Selain itu, peningkatan tingkat resistansi antibiotik bakteri di ruang perawatan intensif menyebabkan infeksi nosokomial oleh bakteri Methicillin-resistant Staphylococcus aureus (MRSA) mencapai 60\%. ${ }^{3}$

Terjadinya Infeksi Saluran Kemih (ISK) pada pasien yang dirawat di rumah sakit disebabkan terutama oleh kateterisasi urin. Semakin lama kateter terpasang maka peluang kateter terkontaminasi oleh mikroba semakin besar, karena penggunaan kateter memungkinkan jalur masuk mikroba ke dalam saluran kemih. ${ }^{4}$

Terdapat berbagai macam patogen yang menyebabkan ISK yang diasosiasikan dengan kateterisasi termasuk Escherichia coli, Klebsiella pneumoniae, Proteus mirabilis, Pseudomonas aeruginosa, Enterobacter, Staphylococcus aureus,
Enterococcus fecalis, Serratia, Candida, dan sebagainya. ${ }^{5,6}$ Akan tetapi, banyak mikroorganisme penyebab ISK merupakan bagian flora usus endogen pasien dan juga dapat diperoleh dengan kontaminasi dari pasien lain atau petugas rumah sakit serta oleh paparan solusi yang telah terkontaminasi atau peralatan yang tidak steril. ${ }^{5}$

\section{METODE PENELITIAN}

Penelitian ini bersifat prospektif dan dilakukan menggunakan metode deskriptif dengan pendekatan cross-sectional untuk mendapatkan gambaran bakteri pada urin pasien yang menggunakan kateter di ruang perawatan intensif RSUP. Prof. Dr. R. D. Kandou Manado. Penelitian ini dilakukan pada periode Desember 2013 sampai Januari 2014. Penelitian menggunakan 20 sampel urin yang diambil dari pasien berusia $>18$ tahun yang menggunakan kateter di ruang perawatan intensif RSUP. Prof. Dr. R. D. Kandou Manado dan diteliti di laboratorium Mikrobiologi Fakultas Kedokteran Universitas Sam Ratulangi Manado. Sampel dibagi ke dalam 6 golongan yang dibagi berdasarkan usia yakni kelompok usia 18-29 tahun, kelompok usia 30-39 tahun, kelompok usia 40-49 tahun, kelompok usia 50-59 tahun, kelompok usia 60-69 tahun dan kelompok usia $\geq 70$ tahun.

Dalam pengambilan sampel, alkohol 70\% digunakan untuk melakukan disin-feksi pada bagian selang kateter yang terbuat dari karet (jangan bagian yang terbuat dari plastik). Setelah itu dilakukan aspirasi urin sebanyak $10 \mathrm{ml}$ dengan menggunakan semprit dan sampel urin diberikan label yang bertuliskan identitas pasien untuk kemudian dikirim ke laboratorium untuk pengamatan dan pemeriksaan. Bakteri diinokulasi pada agar nutrient dan agar MacConkey dan didiamkan selama 24 jam pada suhu $37^{\circ}$ C. Kemudian digunakan pengecatan gram untuk mengidentifikasi sifat Gram dari kuman yang ditemukan. Pengecatan gram dimulai dengan menggenangi preparat dengan cat gram A (larutan Kristal Violet) selama 1 menit dan kelebihan zat warna dibuang dan dibilas 
dengan air yang mengalir. Genangi dengan larutan Lugol, diamkan selama 1 menit dan pereaksi berlebih dibuang dan dibilas dengan air mengalir. Olesan digenangi dengan alkohol tetes demi tetes selama 30 detik atau sampai semua zat warna hilang dan kemudian dibilas dengan air mengalir. Tuang safranin dan didiamkan selama 1 menit dengan kelebihan zat warna dibuang dan dibilas dengan air, setelah itu dikeringkan. Pemeriksaan dilakukan di bawah mikroskop dengan pembesaran 100x menggunakan minyak emensi. Warna ungu mengindikasi bakteri gram (+) sedangkan warna merah menunjukkan bakteri gram (-). Setelah mengetahui jenis gram, identifikasi jenis bakteri dilakukan dimana untuk bakteri gram (+) dilakukan tes adanya hemolisis atau tidak sedangkan untuk bakteri gram (-) perlu dilakukan tes biokimia (TSI agar, Simmon's sitrate, SS).

\section{HASIL PENELITIAN}

Berdasarkan penelitian yang dilakukan, didapatkan 18 sampel yang mengalami pertumbuhan bakteri dan 2 sampel tidak ada pertumbuhan bakteri. Dari 18 sampel bakteri yang bertumbuh terdapat 10 jenis bakteri yang berhasil diidentifikasi yakni Staphylococcus aureus, Candida, Streptococcus, Diplococcus, Proteus vulgaris, Lactobacillus,
Bacillus subtilis, Enterobacter aglomerans, Citrobacter freundii dan Shigella. Dari hasil kultur urin dalam tabel 1 ditemukan 10 jenis bakteri dengan frekuensi yang berbeda untuk setiap jenis bakteri dimana Staphylococus aureus memiliki frekuensi tertinggi yaitu ditemukan pada 9 sampel urin.

Diagram 1 distibusi bakteri berdasarkan kelompok usia menunjukkan kelompok usia 18-29 tahun memiliki jenis bakteri terbanyak yakni sebanyak 7 jenis bakteri dengan frekuensi yang berbeda: Staphylococcus aureus (4 sampel), Candida (1 sampel), Streptococcus (1 sampel), Bacillus subtilis (2 sampel), Enterobacter algomerans (1 sampel), Citrobacter freundii (1 sampel) dan Proteus vulgaris (1 sampel). Kelompok usia 50 - 59 tahun memiliki 5 jenis bakteri yaitu Staphylococcus aureus (2 sampel), Candida (1 sampel), Lactobacillus (2 sampel), Diplococcus (1 sampel) dan Proteus vulgaris (1 sampel).

Diagram 2 distribusi bakteri berdasarkan jenis kelamin menunjukkan Staphylococcus aureus dan Enterobacter algomerans merupakan bakteri yang paling banyak terdapat pada urin sampel berjenis kelamin wanita masing-masing sebanyak 2 sampel. Pada sampel berjenis kelamin pria, Staphylococcus aureus merupakan bakteri yang paling banyak teridentifikasi.

Tabel 1. Frekuensi bakteri hasil kultur urin

\begin{tabular}{lcc}
\hline Tabel 1: Frekuensi Bakteri & Jumlah sample & Persentase (\%) \\
\hline Staphylococcus aureus & 9 & 45.00 \\
Candida & 3 & 15.00 \\
Diplococcus & 3 & 15.00 \\
Proteus vulgaris & 3 & 15.00 \\
Lactobacillus & 2 & 10.00 \\
Bacil subtilis & 2 & 10.00 \\
Enterobacter aglomerans & 2 & 10.00 \\
Citrobacter freundii & 1 & 5.00 \\
Streptococcus & 1 & 5.00 \\
Shigella & 1 & 5.00 \\
Tidak Ada Pertumbuhan & 2 & 10.00 \\
Total Sampel & 20 & \\
\hline
\end{tabular}

Ket: Bakteri yang paling banyak ditemukan adalah Staphylococcus aureus. Bakteri yang paling sedikit ditemukan adalah Citrobacter freundii, Streptococcus, Shigella. 


\section{Jenis Bakteri berdasarkan kelompok usia}



Gambar 1. Jenis bakteri berdasarkan usia. Ket: Bakteri Staphylococcus aureus terdapat pada setiap kelompok usia dan paling banyak ditemukan di dalam kelompok usia 18-29.

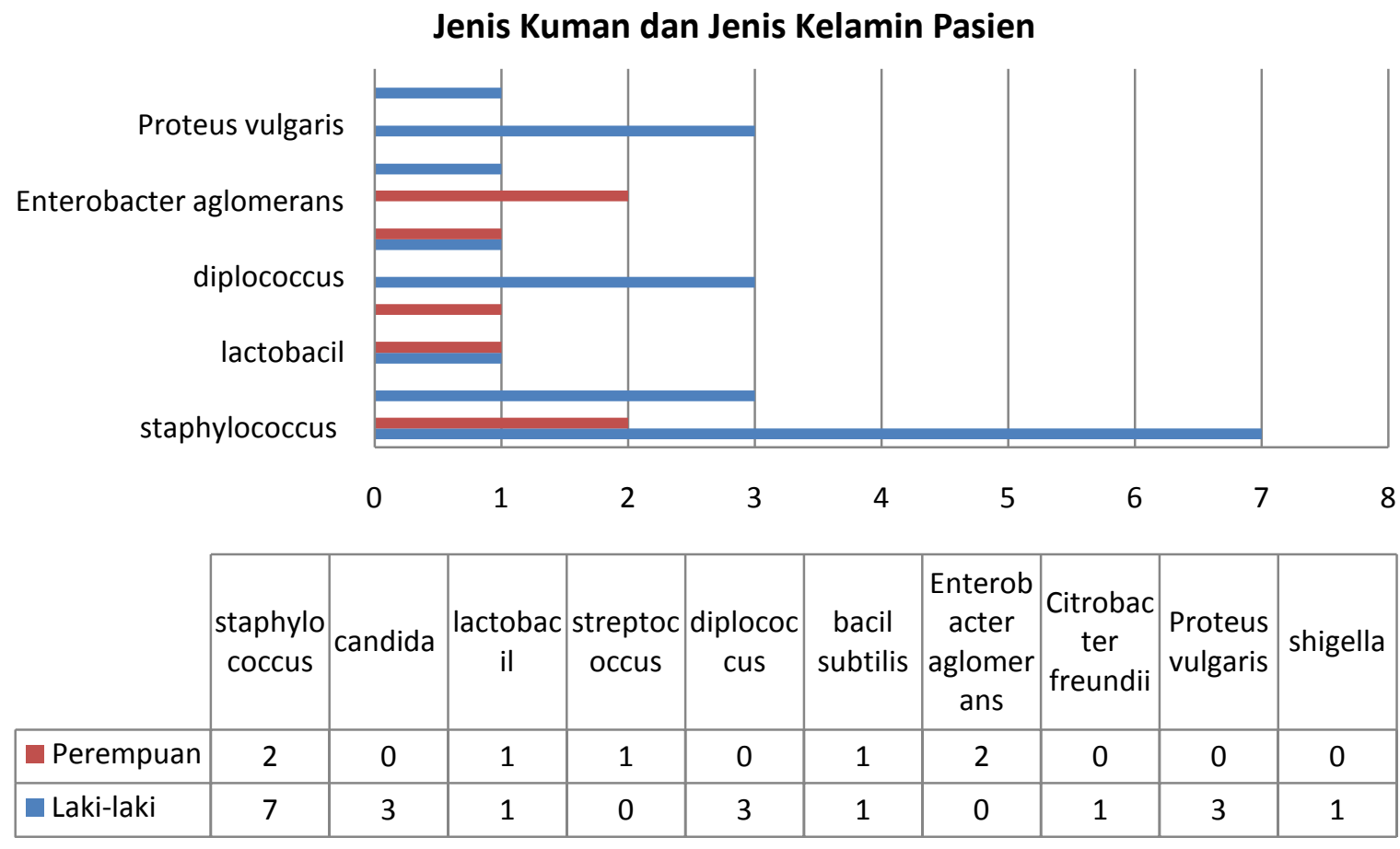

Gambar 2. Jenis kuman dan jenis kelamin pasien. Ket: Staphylococcus aureus paling banyak ditemukan pada pasien pria. 


\section{BAHASAN}

Berdasarkan hasil kultur urin, 10 jenis bakteri yang diidentifikasi adalah Staphylococcus aureus, Candida, Streptococcus, Diplococcus, Proteus vulgaris, Lactobacillus, Bacillus subtilis, Enterobacter aglomerans, Citrobacter freundii dan Shigella. Watts et al mengemukakan bahwa bakteriuria asimtomatik disebabkan oleh berbagai macam bakteri gram positif dan gram negatif seperti Eschericia Coli, Protheus mirabilis, Pseudomona aeruginosa, Providencia stuartii, Staphylococcus aureus dan Enterococcus faecalis. ${ }^{6}$ Balasubramanian et al dalam penelitian mereka di India menemukan 9 jenis bakteri yaitu Proteus mirabilis, Staphylococcus aureus, Staphylococcus epidermidis, Pseudomonas aeruginosa, Eschericia coli, Candida albicans dan Neisseria ghonnorrhaea. $^{7}$ Dalam peneltitian yang dilakukan Mahfouz et al di Arab Saudi, jenis bakteri yang ditemukan adalah Staphylococcus spp, Klebsiella spp, Enterobacter cloacae, Streptococcus, Serratia spp, Eschericia coli, Staphylococcus aureus dan Gram negatif Bacilli yang lain. ${ }^{8}$ Dari hasil yang didapat, terdapat beberapa jenis bakteri yang mirip dengan jenis bakteri yang ditemukan dari ketiga penelitian di atas yaitu Staphylococcus spp, Candida, Streptococcus, Enterobacter spp dan Proteus spp. Perbandingan hasil dari ketiga penelitian tersebut menunjukan bahwa jenis bakteri yang didapat tidak semua sama melainkan hanya beberapa spesies bakteri. Namun, bakteri jenis Staphylococcus aureus ditemukan pada ketiga penelitian yang telah sebelumnya dilakukan. Perbedaan jenis bakteri yang ditemukan kemungkinan disebabkan oleh beberapa faktor diantaranya metode penelitian, alat dan media penelitian yang digunakan, kondisi ruangan dan udara serta kuantitas koloni bakteri yang tumbuh berbeda.

Terdapatnya bakteri-bakteri dalam sampel urin merupakan suatu bentuk infeksi nosokomial dikarenakan adanya kontaminasi yang bersifat eksogen dari lingkungan ruang perawatan intensif.
Shigella merupakan bakteri yang terdapat di anus/feses dengan usus besar sebagai tempat pertumbuhan bakteri. Adapun kontaminasi bakteri Shigella melalui transmisi dari anus ke kateter, dari lingkungan kamar mandi ke tangan melalui kontak langsung dan kemudian dari tangan ke kateter, pakaian, selimut, kasur, dan benda lain di sekitar ruang perawatan intensif yang merupakan media penyebaran. Proteus merupakan flora usus normal pada manusia namun di lingkungan rumah sakit pertumbuhan proteus sebagai gram negatif bacilli biasanya terjadi pada kulit dan mukosa mulut pasien maupun personel rumah sakit yang merupakan sumber infeksi. Kontaminasi Proteus ke sampel urin diduga melalui anus yang berkaitan dengan kemampuan bakteri ini untuk mengerumuni media solid (secara perlahan menutupi permukaan medium secara menyeluruh). Citrobacter spp juga sering di temukan pada kotoran manusia dan berbagai spesimen klinis sehingga kontaminasi di duga berasal dari anus. Eterobacter spp memiliki habitat di tanah dan air meskipun kadang di temukan di kotoran manusia dan saluran pernapasan. Spesies ini dapat menginfeksi pasien di rumah sakit yang mengakibatkan ISK dan bakteremia. Kontaminasi terjadi melalui air saat membasuh tubuh pasien, kontak langsung pengunjung ICU dengan lingkungan luar terutama tanah baik secara langsung maupun tidak langsung dan dari feses. ${ }^{9}$ Juga terdapat bakteri Bacillus subtilis yang tidak seharusnya diidentifikasi sebagai bakteri yang terdapat pada urin. Keberadaan bakteri Bacillus subtilis dikarenakan adanya kontaminasi urin oleh bakteri ini lewat udara. $^{10}$

Jenis bakteri dengan frekuensi tertinggi adalah Staphylococcus aureus yang teridentifikasi dalam 9 dari 18 sampel (50\%) yang mengalami pertumbuhan bakteri. Bakteri ini diduga merupakan jenis MRSA (Methicillin-resistant Staph.aureus) karena berdasarkan literatur biasanya paling banyak menyebabkan infeksi di rumah sakit khususnya di ruang perawatan intensif. Metode penyebaran bakteri ini melalui tangan, sapu tangan, pakaian, debu dengan 
kontak langsung sebagai metode penyebaran yang paling penting. ${ }^{9}$ Terdapat juga pertumbuhan jenis bakteri Candida dan Diplococcus walaupun dengan frekuensi sepertiga dari frekuensi jenis bakteri Staphylococcus aureus yakni teridentifikasi dalam 3 dari 18 sampel (16\%). Akan tetapi Candida tidak dibahas lebih lanjut dalam penelitian ini karena tergolong fungi yang bukan merupakan cakupan penelitian. Dalam literatur, bakteri jenis Eschericia coli merupakan jenis bakteri yang paling banyak ditemukan dalam urin. Watts et al mengemukakan bahwa bakteri Eschericia coli merupakan penyebab paling umum infeksi saluran kemih yang diakibatkan oleh infeksi nosokomial termasuk bakteriuria asimtomatik pada pasien yang dikateterisasi. ${ }^{6}$ Colgan et al juga menyebutkan Eschericia coli sebagai bakteri yang paling banyak terisolasi dari pasien dengan bakteriuria asimtomatik. ${ }^{11}$ Hal ini bertentangan dengan hasil identifikasi yang didapat dimana Staphylococcus aureus merupakan jenis bakteri yang paling banyak ditemukan. Akan tetapi terdapat beberapa penelitian yang paling banyak menemukan jenis bakteri Staphylococcus aureus seperti penelitian yang dilakukan oleh Mahfouz et al di Australia dan penelitian yang dilakukan oleh Balasubramanian et al di India yang menemukan jenis bakteri Staphylococcus sebagai jenis bakteri yang paling banyak teridentifikasi dengan distribusi sebanyak $33.4 \%$ dan $38 \%$ berturut-turut. $^{7,8}$

Dari distribusi jenis bakteri berdasarkan kelompok usia, kelompok usia 18-29 tahun memiliki jenis bakteri terbanyak yakni sebanyak 7 jenis bakteri dengan frekuensi yang berbeda. Kelompok usia. Kedua kelompok usia ini menunjukan pertumbuhan bakteri dengan frekuensi dan ragam yang jauh lebih banyak dibandingkan kelompok usia yang lain. Akan tetapi, hasil distribusi jenis bakteri ini berbanding lurus dengan dsitribusi sampel berdasarkan kelompok usia. Distribusi sampel berdasarkan kelompok usia menunjukkan sebanyak 7 sampel berasal dari kelompok usia 18-29 tahun dan 6 sampel berasal dari kelompok usia 50-59 tahun. Oleh karena itu, jenis dan frekuensi bakteri di setiap kelompok usia yang bervariasi diakibatkan oleh ketidakmerataan distribusi sampel pada masingmasing kelompok usia.

Dari distribusi jenis bakteri berdasarkan jenis kelamin, sampel dengan jenis kelamin Pria memiliki 8 dari 10 jenis bakteri dengan total frekuensi sebanyak 20: Staphylococcus (7 sampel) , Candida (3 sampel), Diplococcus (3 sampel), Proteus vulgaris (3 sampel) , Lactobacillus (1 sampel), Bacillus subtilis (1 sampel), Citrobacter freundii (1 sampel) dan Shigella (1 sampel). Di sisi lain, sampel dengan jenis kelamin Wanita hanya memiliki 5 dari 10 jenis bakteri dengan total frekuensi sebanyak 7: Staphylococcus (2 sampel), Streptococcus (1 sampel), Lactobacillus (1 sampel), Bacillus subtilis (1 sampel) dan Enterobacter aglomerans (2 sampel). Hasil ini mengindikasikan bahwa bakteri dengan jenis yang lebih beragam dan frekuensi yang lebih tinggi ditemukan pada sampel berjenis kelamin pria. Prevalensi bakteri pada wanita secara umum lebih tinggi dari pada pria. ${ }^{11}$ Akan tetapi, bakteri pada pria teridentifikasi lebih banyak dikarenakan oleh beberapa faktor antara lain jumlah pasien pria yang lebih banyak, jenis penyakit dari hasil diagnosis dan lama penggunaan kateter.

Menurut Colgan et al jenis dan distribusi bakteri bervariasi berdasarkan usia, jenis kelamin, aktivitas seksual dan penyakit. ${ }^{11}$ Menurut Nelius et al, prevalensi pada wanita muda, pre-menopause dan tidak hamil berada diantara $0.7 \%$ dan $5.2 \%$ dan meningkat sesuai dengan pertambahan usia dan aktifitas seksual; prevalensi pada wanita hamil berada diantara $2 \%$ dan $7 \%$; prevalensi pada pria muda berada diantara $0 \%$ dan $1.5 \%$ dan prevalensi pada orang tua tercatat sebanyak $25 \%-50 \%$ pada wanita dan $15 \%-40 \%$ pada pria. $^{12}$ Data ini menunjukkan bahwa pasien dengan usia lanjut baik pria maupun wanita memiliki prevalensi yang lebih tinggi dibandingkan pasien yang masih muda. Akan tetapi, hasil yang didapat menunjukan prevalensi tertinggi berada pada kelompok usia 18-29 tahun dibandingkan dengan pasien usia lanjut dalam kelompok usia 50-59 tahun. 
Nelius et al juga menambahkan untuk pasien yang mengidap penyakit kronik, prevalensi bervariasi tergantung pada jenis penyakit yang diderita sedangkan prevalensi pada pasien yang dikateterisasi bergantung pada jenis kateter yang digunakan, durasi penggunaan kateter, kualifikasi personel kesehatan dan sistem serta perawatan kateter. ${ }^{12}$ Oleh karena itu, kondisi pasien, penyakit yang diderita, jenis dan durasi kateter yang digunakan, perawatan kateter dan kualifikasi personel kesehatan merupakan faktor yang menyebabkan ketidaksesuaian hasil yang didapat dengan hasil penelitian sebelumnya.

\section{SIMPULAN}

Dari pemeriksaan 20 sampel urin pasien yang menggunakan kateter ditemukan 18 sampel memiliki pertumbuhan bakteri dan 2 sampel yang tidak memiliki pertumbuhan bakteri. Terdapat 10 jenis bakteri yang berhasil diidentifikasi yaitu Staphylococcus aureus, Candida, Streptococcus, Diplococcus, Proteus vulgaris, Lactobacillus, Bacillus subtilis, Enterobacter aglomerans, Citrobacter freundii dan Shigella. Jenis bakteri yang paling banyak ditemukan adalah Staphylococcus aureus. Ragam dan prevalensi jenis bakteri berbeda untuk setiap penelitian tergantung dari metode dan alat yang digunakan, kondisi kesehatan pasien dan kuantitas koloni bakteri dalam urin.

\section{SARAN}

Perlu dilakukan penelitian lebih lanjut tentang pola bakteri pada urin pasien yang menggunkan kateter dengan sampel yang lebih banyak dan merata untuk setiap kelompok usia dan jenis kelamin untuk mendapatkan data distribusi bakteri berdasarkan kelompok usia dan jenis kelamin yang lebih akurat. Perlu dilakukan penelitian lebih lanjut tentang pola bakteri pada urin pasien yang menggunakan kateter yang mencakup durasi penggunaan kateter dan riwayat penyakit pasien dengan mempertimbangkan efek riwayat penyakit yang berkaitan dengan infeksi bakteri terutama pada saluran kemih dan kemungkinan penggunaan antibiotika untuk penyembuhan penyakit bagi distribusi bakteri, jenis bakteri dan kuantitas koloni bakteri dalam urin. Pada penelitian berikutnya, pengambilan dan pengujian sampel perlu dilakukan lebih teliti dan lebih hati-hati mengingat adanya kemungkinan kontaminasi bakteri secara eksternal yang dapat mempengaruhi tingkat akurasi hasil yang ditemukan.

\section{UCAPAN TERIMA KASIH}

Ucapan terima kasih kepada Dr. Constantien Kountul, SpMK(K) dan DR.Dr. John Porotu'o, MHA,Msi,AIFO, serta semua pihak yang secara langsung maupun tidak langsung telah memberi ide dan gagasan kepada penulis sehingga penulis dapat menyelesaikan artikel ini.

\section{DAFTAR PUSTAKA}

1. Better Health Channel. Better Health Gov. [Online]; $2012 . \quad$ Available from: http://www.betterhealth.vic.gov.au/bh cv2/bhcarticles.nsf/pages/Urinary_catheteris ation

2. Webster M. Merriam Webster. [Online].; 2014. Available from: www.merriamwebster.com/dictionary/urine.

3. Inweregbu $\mathrm{K}$, Dave J, Pittard A. Nosocomial Infection. Continuing Education in Anaesthesia, Critical Care \& Pain. 2005; V(1).

4. Arisandy N. Kumpulan Skripsi Keperawatan. [Online].; 2013. Available from: http://linkskipsi.blogspot.com/2013/0 9/hubungan-lamanya-kateter-terpasang 22.html.

5. Taiwo SS, Aderounmu AOA. Catheter Associated Urinary Tract Infection: Aetiologic Agents and Antimicrobial Susceptibility Pattern in Ladoke Akintola University Teaching Hospital, Osogbo, Nigeria. African Journal of Biomedical Reasearch. 2006 September;IX.

6. Watts ER, Hancock V,Ong YCL, Vejborg RM, Mabbett AN, Makrina T, et al. Eschericia coli Isolates Causing Asymptomatic Bacteriuria in catheterized and Noncatherized Individual Posses Similar Virulence Properties. American Society for Miocrobiolgy. 2010 April;48(7) 
508 Jurnal e-Biomedik (eBM), Volume 2, Nomor 2, Juli 2014, hlm. 501-508

7. A B, K C, A RSAJ, G A. Isolation and identification of microbes from biofilm of Urinary catheters and antimicrobial Susceptibility evalution. Asian Pacific Journal of Tropical Biomedicine. 2012 Desember; 28.

8. Mahfouz AA, Al-azraqi TA, Abbag FI, AlGamal MN, Seef S, Bello CS. Nosocomial infections in a neonatal intensive care unit in south-western Saudi Arabia. Eastern Mediterranean Health Journal. 2010; XVI(1)

9. Greenwood D, Slack RCB, Peutherer JF, Barer MR. MEDICAL MICROBIOLOGY: A GUIDE TO MICROBIAL INFECTIONS: PATHOGENESIS, IMMUNITY, LABORATORY DIAGNOSIS AND CONTROL. $17^{\text {th }}$ ed. Greenwood D, Slack RCB, Peutherer JF, Barer MR, editors.
China: CHURCHILL LIVINGSTONE ELSEVIER LIMITED; 2007

10. Kirk E. Bacillus Subtilis. [Online] 2009. Available from: http://web.mst.edu/ microbio/BIO221 _2009/B_subtilis.html

11. Colgan $R$, NICOLLE $L$ McGLONE A, HOOTON T. Asymptomatic Bacteriuria in Adults. American Family Physician. 2006 September; 74(6)

12. Thomas Nelius SFaJSN. Asymptomatic Bacteriuria: Significance for Different Patient Population . Scientific. Lubbock: Texas Tech University Health Sciences Center, Departements of Urology and Microbiology; 2011. Report No : ISBN: 978-953-307-757-4. 